\title{
EFFECT OF CHEMISTRY VARIATIONS \\ ON THE WELDABILITY OF COMMERCIALLY \\ PURE VANADIUM SHEET
}

Thomas G. Glenn

George W. Elliston

Carl M. Edstrom

Wilbur L. Johns
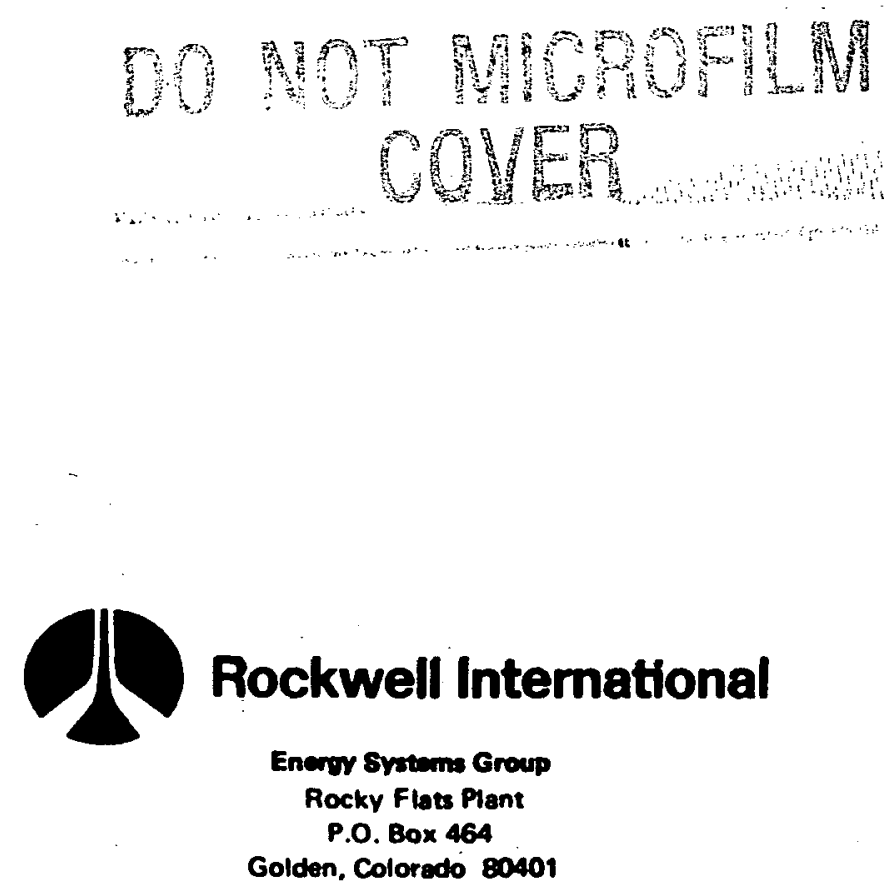

U. S. DEPARTMENT OF ENERGY CONTRACT OE-ACO4-76DPO3533 


\section{DISCLAIMER}

This report was prepared as an account of work sponsored by an agency of the United States Government. Neither the United States Government nor any agency Thereof, nor any of their employees, makes any warranty, express or implied, or assumes any legal liability or responsibility for the accuracy, completeness, or usefulness of any information, apparatus, product, or process disclosed, or represents that its use would not infringe privately owned rights. Reference herein to any specific commercial product, process, or service by trade name, trademark, manufacturer, or otherwise does not necessarily constitute or imply its endorsement, recommendation, or favoring by the United States Government or any agency thereof. The views and opinions of authors expressed herein do not necessarily state or reflect those of the United States Government or any agency thereof. 


\section{DISCLAIMER}

Portions of this document may be illegible in electronic image products. Images are produced from the best available original document. 


\section{EFFECT OF CHEMISTRY VARIATIONS \\ ON THE WELDABILITY OF COMMERCIALLY \\ PURE VANADIUM SHEET}

Thomas G. Glenn

George W. Elliston

Carl M. Edstrom

Wilbur L. Johns

R. D. Howerton, Editor

I. C. Delaney, Compositor

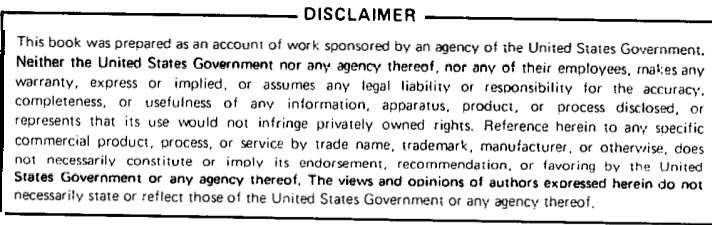

This bock was prepated as an account ot work sponsored by an agency of the United States Government.

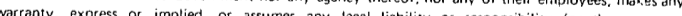

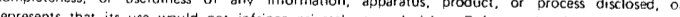
commercial product, orocess, or service by irade name, trademark, manufacurer, or othervise, does

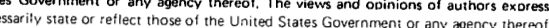

\section{SUBJECT DESCRIPTORS}

Vanadium

Electron Beam Welding

Chemistry Effects

\footnotetext{
ROCKWELL INTERNATIONAL ENERGY SYSTEMS GROUP ROCKY FLATS PLANT P.O. BOX 464 GOLDEN, COLORADO 80401

Prepared under Contract DE-AC04-76DPO3533 for the Albuquerque Operations Office

U.S. Department of Energy
} 
RFP-3217 
Abstract $\ldots \ldots \ldots \ldots \ldots \ldots \ldots \ldots \ldots \ldots \ldots \ldots \ldots$

Introduction $\ldots \ldots \ldots \ldots \ldots \ldots \ldots \ldots \ldots \ldots \ldots$

Experimental Procedure $\ldots \ldots \ldots \ldots \ldots \ldots \ldots \ldots \ldots \ldots \ldots$

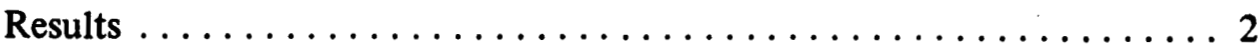

Metallographic Sections. ................... 2

Hardness Traverses $\ldots \ldots \ldots \ldots \ldots \ldots \ldots \ldots \ldots \ldots \ldots \ldots$

Tensile Tests $\ldots \ldots \ldots \ldots \ldots \ldots \ldots \ldots \ldots \ldots \ldots \ldots$

Regression Analysis. ...................4

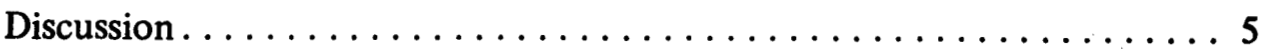

Summary of Results $\ldots \ldots \ldots \ldots \ldots \ldots \ldots \ldots \ldots \ldots \ldots \ldots \ldots$

Recommended Future Work $\ldots \ldots \ldots \ldots \ldots \ldots$

References......................... 6

Illustrations (Figures 1-19) $\ldots \ldots \ldots \ldots \ldots \ldots \ldots \ldots \ldots$ 


\section{A C K N O W LED G M E N T}

The authors would like to express appreciation to the following individuals for their contribution to this work: Barbara Kerr for the regression analysis, Dave Millard for electron beam remelting test materials, Joe Doyle and Dave Riefenburg for electron microprobe work. 


\title{
EFFECT OF CHEMISTRY VARIATIONS
}

\section{ON THE WELDABILITY OF COMMERCIALLY \\ PURE VANADIUM SHEET}

\author{
Thomas G. Glenn, George W. Elliston, Carl M. Edstrom, \\ and Wilbur L. Johns
}

\begin{abstract}
Tensile tests and metallographic examinations were done on electron beam welds on six different chemistries of vanadium. The welds were found to maintain base metal strengths even though large grains were present in the fusion zone. Nitrogen and oxygen were found to be the most effective strengtheners. The weld and surrounding area in material containing high nitrogen and oxygen exhibited higher hardness than the base metal.
\end{abstract}

\section{INTRODUCTION}

Vanadium is a body-centered cubic metal that maintains this phase up to the element's melting point. Some physical properties of interest in welding vanadium compared to 304 stainless steel are shown in Table 1. Because of the high melting temperature and high thermal diffusivity of vanadium, the melting efficiency is considerably less than that of 304 stainless steel. Figure 1 shows a comparison of two welds made with identical parameters on sheets of vanadium and 304 stainless. The widths of the two welds are almost the same; however, the vanadium has about one-half the penetration and melt area. Grains in the vanadium weld are large and epitaxial in nature. The edge of the fusion zone is difficult to distinguish, so arrows have been placed on the Figure 1 photomicrograph of vanadium to emphasize the edge of the weld.

Welding of commercially pure vanadium for weapons application began at Rocky Flats in 1979. At that time very little material was available within the weapons complex or from commercial sources. By November 1980, Rocky Flats had received a shipment of vanadium from United Mineral Incorporated and another from Teledyne Wah Chang Incorporated. Because of the variability in the chemical composition between shipments and between different plates of the shipment from Wah Chang, an investigation was initiated to determine the effect of these variations on mechanical properties and weldability. The major objective of this study was to discover the differences among the materials investigated and to use the information to establish a specification for future orders of vanadium.

The chemistry variation of the materials investigated is shown in Table 2. The chemical analyses of oxygen, nitrogen, and carbon were done with LECO furnace methods; the nitrogen values were checked using wet chemistry techniques. The silicon, aluminum, niobium, and iron contents were determined by mass spectrometry with a check of aluminum, silicon, and iron by the atomic adsorption technique.

Chemistries shown in Table 2 span the variation of materials used at Rocky Flats to date. Material designated as UM was that received from United Mineral Incorporated. The UM + Si material was United Mineral source material with silicon, which was added at Rocky Flats. The remaining materials were obtained from different plates of the Wah Chang shipment.

Materials designated as $\mathrm{UM}$ and $\mathrm{UM}+\mathrm{Si}$ were the highest in interstitial content. The A5-1 and A2-1 materials were similar in chemistry, both having low interstitials and high niobium. The A6-1 material was low in interstitials and moderate in niobium, while B6-1 was low in all residual elements except silicon. All of the materials tested contained a moderate amount of silicon.

Samples of each of these materials were electron beam welded and were machined into transverse and longitudinal tensile specimens. Results of 
TABLE 1. Some Physical Properties of Vanadium

\begin{tabular}{|c|c|c|}
\hline Property & Vanadium & $304 \mathrm{~S} / \mathrm{S}^{*}$ \\
\hline Melting Point $\left({ }^{\circ} \mathrm{C}\right)$ & 1900 & 1430 \\
\hline $\begin{array}{l}\text { Thermal Conductivity } \\
\left(\mathrm{cal} / \mathrm{sec} \cdot \mathrm{cm} \cdot{ }^{\circ} \mathrm{C}\right)\end{array}$ & 0.074 & 0.038 \\
\hline $\begin{array}{l}\text { Thermal Diffusivity } \\
\left(\mathrm{cm}^{2} / \mathrm{sec}\right)\end{array}$ & 0.1009 & 0.0437 \\
\hline $\begin{array}{l}\text { Latent Heat of Fusion } \\
\text { (cal/g) }\end{array}$ & 78.4 & 71.3 \\
\hline$\overline{\text { S/S }}$ - Stainless Steel. & & \\
\hline
\end{tabular}

TABLE 2. Chemical Analyses of the Materials Tested (Values in parts per million)

\begin{tabular}{|c|c|c|c|c|c|}
\hline Material Type & 0 & $\mathrm{~N}$ & $\mathrm{Si}$ & Al & $\mathrm{Nb}$ \\
\hline $\mathbf{U M}+\mathbf{S i}$ & 1841 & 210 & 2400 & 114 & 200 \\
\hline UM & 168 & 523 & 1410 & 570 & 200 \\
\hline A5-1 & 257 & 150 & 1018 & 86 & 7200 \\
\hline A2-1 & 276 & 140 & 1170 & 82 & 7200 \\
\hline A6-1 & 381 & 140 & 1503 & 83 & 1700 \\
\hline B6-1 & 381 & 110 & 1134 & 102 & 700 \\
\hline
\end{tabular}

NOTE: Carbon Content in each of the listed materials was about $100 \mathrm{ppm}$. See the text for clarification of material type.
TABLE 3. Electron Beam Welding

Parameters Used for the Study

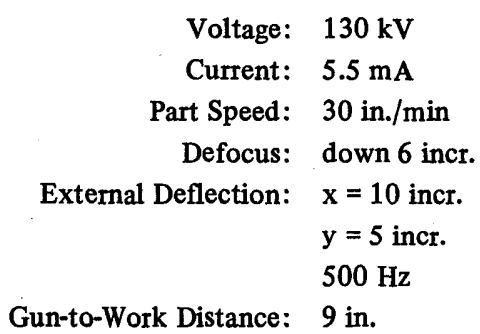

welded together. Two metallography, as well as eight transverse and one longitudinal weld specimen, were tested from each material. Figure 3 shows the design of the transverse weld specimens.

Longitudinal weld specimens were the same except that the weld ran parallel to the axis of the specimen. Tensile tests were done at room temperature, $-50^{\circ} \mathrm{C}$, and $-100{ }^{\circ} \mathrm{C}$ for the transverse weld specimens. Because of the limited material available, the longitudinal specimens were tested only at room temperature.

The specimens were welded with a $7.5 \mathrm{~kW}$ Hamilton Standard electron beam welder using the parameters shown in Table 3. The combination of defocus and external deflection shown in Table 3 increased the beam spot size by 0.010 in. $(0.25 \mathrm{~mm})$ in the $x$ direction and $0.015 \mathrm{in} .(0.38 \mathrm{~mm})$ in the $y$ (beam travel) direction. The parameters were developed to obtain $0.060 \mathrm{in}$. $(1.52 \mathrm{~mm})$ penetration, and once established, were kept constant throughout the entire test.

\section{RESULTS}

\section{Metallographic Sections}

\section{EXPERIMENTAL PROCEDURE}

A flow diagram of the experimental procedure is shown in Figure 2. The material was rolled to 0.100 in. $(2.54 \mathrm{~mm})$ thickness and then vacuum annealed at $1000^{\circ} \mathrm{C}$ for $1.5 \mathrm{hr}$. Coupons were machined from the plates and electron beam
Figure 4 is a cross-section of the UM material, perpendicular to the weld axis. The parent material on the right shows smaller grain size than that on the left, indicating the right piece was not annealed properly. All of the other specimens from the UM material subsequently were checked (by hardness) 
and were found to be in the proper annealed condition. Figure 4 shows the epitaxial nature of the grain formation within the weld. Grains on the right side of the weld are smaller than on the left because of the smaller parent material grains. The area of the heat affected zone, which sustained grain growth, was no more than 0.010 in. (0.25 $\mathrm{mm}$ ) from the edge of the weld bead and is typical of all the materials tested. Figure 5 is a section through the same weld as Figure 4, except that the section has been tilted $30^{\circ}$ from the previous orientation. As expected, this view shows the grains of the weld bead are elongated, and are oriented so that they "trail away" from the direction of beam travel.

Figure 6 is a cross-section perpendicular to the axis of the $\mathrm{UM}+\mathrm{Si}$ weld. The parent material and weld were scanned using a Cameca electron microprobe, and no segregation of the silicon, oxygen, nitrogen, or carbon could be detected within the 1-micron resolution capability of the machine. Figure 7 is a $400 \mathrm{X}$ photomicrograph of the weld area. The cellular structure evident here was not found on any of the other welds. Work on these specimens at Lawrence Livermore National Laboratory (LLNL), using the Secondary Ion Mass Spectrometry (SIMS) technique, has shown, qualitatively, the cell boundaries to be higher than surrounding material in silicon content. ${ }^{1}$

Figure 8 is a cross-section of the weld of the A5-1 material. Metallographically, this weld is very similar to those in the other Wah Chang material. All of the welds sectioned had similar depths and widths, with $0.055-0.060$ in. $(1.40-1.52 \mathrm{~mm})$ penetration and depth-to-width ratios of 0.83 to 0.87 .

\section{Hardness Traverses}

Knoop hardness tests were done in the weld areas to a distance of about $0.200 \mathrm{in}$. $(5.08 \mathrm{~mm})$ from the weld centerline. Figures 9 and 10 show the results of these tests. The cross-hatched area represents the fusion zone; the,dashed lines labeled "base metal" are an average of the three data points farthest away from the weld. The materials designated at $\mathrm{UM}$ and $\mathrm{UM}+\mathrm{Si}$ exhibited an area of increased hardness within about 0.100 in. $(2.54 \mathrm{~mm})$ of the weld centerline. The increased hardness extended significantly beyond any visually apparent heat affected zone. These two materials (UM and $\mathrm{UM}+\mathrm{Si}$ ) contained the highest percentage of interstitial residual elements (oxygen and nitrogen), while the materials containing lower interstitials showed little or no hardening near the weld.

\section{Tensile Tests}

Of the 46 transverse welds tested, all failed outside the weld fusion zone, and all but two failed greater than 0.080 in. $(2.03 \mathrm{~mm})$ away from the weld centerline. Figure 11 is a photograph of a typical failure. All showed significant necking. A crosssection of this same joint is shown in Figure 12. Failure analysis of the fracture surfaces of transverse and longitudinal specimens of the A5-1 material was conducted using a scanning electron microscope (SEM). A $100 \mathrm{X}$ picture of the fracture surface of this material, which was tested at room temperature, is shown in Figure 13. This fracture is through the parent material of a transverse weld specimen. The relatively flat horizontal band through the center of the photograph is the area of final fracture. Slip bands from ductile necking appear above and below this area. The final fracture surface appears relatively smooth with some ductile dimple character. Figure 14 is a $1000 \mathrm{X}$ picture of the edge of this area. SEM pictures of the fracture surface of a similar specimen tested at $-100{ }^{\circ} \mathrm{C}$ showed the same characteristics as those of the room temperature test. A 100X SEM photograph of the fracture surface of a longitudinal specimen is shown in Figure 15. The final fracture surface of this weld, which has been forced to occur in the weld, is ductile dimple in character. Figure 16 is a $1000 \mathrm{X}$ photograph of the final fracture area of this specimen.

The strengths of the tensile specimens varied significantly, depending on the residual elements present in the vanadium. A summary of the results of the room temperature transverse specimen tests are presented in Table 4. Each value shown represents an average of four tensile tests. As mentioned, these strengths represent base metal 
TABLE 4. Chemistry Variation Effect on the Room-Temperature Tensile Properties of Vanadium Transverse Weld Specimens

\begin{tabular}{|c|c|c|c|c|c|c|c|c|}
\hline Material Type & 0 & $\mathbf{N}$ & $\mathbf{S i}$ & $\mathrm{Al}$ & $\mathrm{Nb}$ & $\mathrm{Fe}$ & $\begin{array}{c}\text { YS/UTS } \\
\text { (ksi) }\end{array}$ & $\begin{array}{c}\text { Elongation } \\
(\%)\end{array}$ \\
\hline $\mathbf{U M}+\mathbf{S i}$ & 1841 & 210 & 2400 & 114 & 200 & 638 & $68.4 / 75.2$ & 22.7 \\
\hline UM & 168 & 523 & 1410 & 570 & 200 & 645 & $42.5 / 50.8$ & 16.5 \\
\hline A5-1 & 257 & 150 & 1018 & 86 & 7200 & 200 & $32.2 / 40.2$ & 23.0 \\
\hline A2-1 & 276 & 140 & 1170 & 82 & 7200 & 282 & $32.2 / 41.0$ & 21.3 \\
\hline A6-1 & 381 & 140 & 1503 & 83 & 1700 & 400 & $28.4 / 37.6$ & 22.3 \\
\hline B6-1 & 381 & 110 & 1134 & 102 & 700 & 264 & $26.7 / 35.5$ & 29.9 \\
\hline
\end{tabular}

failures. The ductility (percent elongation) of these tests was moderately high except for the UM material, which was high in nitrogen and aluminum.

Figures 17 and 18 show the effect of lowering testing temperature on the tensile properties of the transverse weld specimens. Each point plotted in these figures is an average of two tests except the room temperature joints, which are an average of four tests. Lowering the testing temperature resulted in significant increases in tensile strengths (Figure 17), with little effect on ductility (Figure 18). The exception to this, however, was the UM material, which began to lose ductility at $-100^{\circ} \mathrm{C}$. Failures of all these tests occurred in the base metal.

Room-temperature tests of one longitudinal specimen from each material resulted in strength values similar to the base metal failures of the transverse specimens, except for those from the $\mathrm{UM}$ and $\mathrm{UM}+\mathrm{Si}$ materials. These longitudinal tests showed a slightly higher strength than the transverse specimens of the same material. The strength increase correlates with the increased hardness, as previously described, in the weld area of these two materials. Table 5 shows the results of the longitudinal tests.

Although all the materials tested had identical heat treatments, they exhibited differences in grain size and hardness. Figure 19 shows the correlation between hardness and strength, and between grain size and strength. The grain size relationship is not
TABLE 5. Results of the Room-Temperature Longitudinal Weld Tensile Tests

\begin{tabular}{llllc} 
Material Type & & $\begin{array}{c}\text { YS/UTS } \\
(\mathrm{ksi})\end{array}$ & & $\begin{array}{c}\text { Elongation } \\
(\%)\end{array}$ \\
\cline { 1 - 1 } \cline { 5 - 6 } $\mathrm{UM}+\mathrm{Si}$ & & $61.8 / 79.0$ & & 28.0 \\
$\mathrm{UM}$ & & $43.7 / 56.6$ & & 25.0 \\
$\mathrm{~A} 5-1$ & & $31.7 / 40.9$ & & 23.0 \\
A2-1 & & $30.9 / 41.3$ & & 21.0 \\
A6-1 & & $27.4 / 36.4$ & & 23.0 \\
B6-1 & & $24.7 / 33.9$ & & 24.0
\end{tabular}

considered significant except that the materials with high amounts of residual impurities form smaller grains for a given heat treatment than the higher purity materials. If the grain size itself were significantly affecting strength, failures of transverse weld specimens would be expected to occur within the large-grained weld bead.

\section{Regression Analysis}

To better understand the hardening effect of individual elements on the vanadium tested, a regression analysis was done with two linear models. These models related ultimate strength of the base metal failures to the chemical composition of the materials. The equations of these models were as follows: 
(Model 1)

$$
\begin{aligned}
\mathrm{UTS}=\mathrm{B}_{0}+\mathrm{B}_{1}(\mathrm{O})+\mathrm{B}_{2}(\mathrm{~N})+\mathrm{B}_{3}(\mathrm{Si}) \\
+\mathrm{B}_{4}(\mathrm{Al})+\mathrm{B}_{5}(\mathrm{Nb}+\mathrm{Fe})
\end{aligned}
$$

(Model 2)

$$
\begin{aligned}
\mathrm{UTS}=\mathrm{B}_{0}+\mathrm{B}_{1}(\mathrm{O})+\mathrm{B}_{2}(\mathrm{~N}) \\
+\mathrm{B}_{3}(\mathrm{Si}+\mathrm{Al}+\mathrm{Nb}+\mathrm{Fe})
\end{aligned}
$$

where UTS is the ultimate tensile strength in thousands of pounds per square inch (ksi), $B_{0}$ through $B_{5}$ are coefficients to be estimated, and $\mathrm{O}, \mathrm{N}, \mathrm{Si}, \mathrm{Al}, \mathrm{Nb}$, and $\mathrm{Fe}$ are the quantity of the individual residual elements expressed in parts per million (ppm).

The study resulted in the following least squares estimates of the coefficients:

(Model 1)

$$
\begin{aligned}
\mathrm{UTS}=20.539+0.025(\mathrm{O})+0.056(\mathrm{~N}) \\
-0.001(\mathrm{Si})-0.004(\mathrm{Al}) \\
+0.001(\mathrm{Nb}+\mathrm{Fe})
\end{aligned}
$$

(Model 2)

$$
\begin{array}{r}
\mathrm{UTS}=18.327+0.023(\mathrm{O})+0.049(\mathrm{~N}) \\
+0.001(\mathrm{Si}+\mathrm{Al}+\mathrm{Nb}+\mathrm{Fe})
\end{array}
$$

The correlation coefficients of these equations were both 0.998 .

\section{DISCUSSION}

The large grain size is an area of concern with these welds in relatively thin sections where one or two grains can span the entire thickness of material. As indicated by the change in observed weld structure due to orientation change, attempts to control grain size should be preceded by developing a standard method of characterizing grain size and orientation.

The cellular structure found in the weld of the $\mathrm{UM}+\mathrm{Si}$ material indicates an extent of constitutional supercooling considerably less than a grain diameter caused by the silicon impurity. This is the result of a moderately steep thermal gradient in the liquid and a relatively slow solidification rate, which are considered desirable conditions for weld solidification. ${ }^{2}$ The microsegregation that was not detectable by electron microprobe is expected to be identifiable by a SIMS capability soon to be operational at Rocky Flats.

An investigation is being made of the two possible causes of observed hardening of the area within $0.100 \mathrm{in} .(2.54 \mathrm{~mm})$ of the centerline of the weld for the two high interstitial materials. The first possible cause is that the interstitials diffuse to the area heated by the weld because lower energy interstitial sites are available there than at areas of lower temperature. From the graph of Figure 19, an increase in hardness of 20 Knoop units should correspond to an increase in ultimate tensile strength of about $9 \mathrm{ksi}(62 \mathrm{MPa})$. From the hardening coefficients of Equation 4, this corresponds to an increase of 391-ppm oxygen or 187-ppm nitrogen. To test this, further experiments are planned to take samples from the weld and base metal and do chemical analyses on these samples.

The second hypothesis suggests the two materials in question exhibit classic age-hardening character from either or both the oxygen and nitrogen solutes. If this is the mechanism, additional solution of the interstitials would occur upon heating, and probably would form coherent precipitates upon fast cooling. Vanadium-carbon alloys have been found to age-harden at carbon levels of 300 ppm and greater, but the materials of this investigation contained 100-ppm carbon or less. Investigators of the solid solubility of oxygen and nitrogen in vanadium generally agree that it can dissolve levels greater than $2000 \mathrm{ppm}$ of either element at room temperature. ${ }^{3,4}$ Therefore, one would not normally expect age-hardening characteristics in either of the two materials exhibiting this hardening phenomenon. If this is the mechanism, specimens quenched from near the melting temperature should be harder than those slow-cooled from the same temperature. Tests of this type are planned. Also, if this is the mechanism, precipitates should be found in slow-cooled samples of these materials. So far, none have been found.

Regression analysis of the hardening coefficients of impurity elements indicates that annealed, highpurity vanadium should have an ultimate tensile strength of about $20 \mathrm{ksi}(138 \mathrm{MPa})$. Although Equations 3 and 4 both have high correlation 


\section{RFP-3217}

coefficients, a student $t$ evaluation of the individual coefficients show those for nitrogen, silicon, and aluminum in Equation 3 to be of low significance. All of the coefficients of Equation 4 were significant using this test. The hardening coefficients of 0.023 for oxygen and 0.049 for nitrogen in Equation 4 agree quite well with those found for electrorefined vanadium by Keith and Iverson ${ }^{5}$ (who reported 0.026 for oxygen and 0.044 for nitrogen) and Matthews et al. (0.029 and 0.048, respectively). ${ }^{6}$ These two referenced studies investigated material with very low amounts of silicon, aluminum, niobium, and iron. The present study indicates similar hardening effects of oxygen and nitrogen, even with the other impurities present.

\section{SUMMARY OF RESULTS}

The results can be summarized as follows:

(1) Electron beam welds in annealed vanadium of varied residual impurity content maintained base metal strength, with failures typically occurring in the base metal.

(2) Large, elongated grains were present in the welds of all the materials tested. The size of the grains within the weld were affected by the grain size of the base metal.

(3) The fusion zone and surrounding base metal within 0.100 in. $(2.54 \mathrm{~mm})$ of the weld centerline exhibited a hardening of 20-30 Knoop units over the base metal in the two high interstitial materials.

(4) Base metal and the weld metal failures of the materials tested exhibited a ductile dimple failure mode.

(5) The base metal strength was affected significantly by the quantity of oxygen and nitrogen present, with little affect by the amounts of silicon, aluminum, iron, and niobium in the metal.

(6) The ductility of the vanadium base metal was unaffected by testing temperatures down to $-100{ }^{\circ} \mathrm{C}$, except for the high-nitrogen, highaluminum material.

\section{RECOMMENDED FUTURE WORK}

The following items are recommended for future work on vanadium welding:

(1) Similar tests as these should be conducted using gas-tungsten-arc (GTA) welding.

(2) Experiments designed to refine the grains within vanadium welds would be useful.

(3) Experiments to determine the origin of the weld area hardening phenomenon should be conducted.

(4) Similar tests are planned for a high-silicon, low-oxygen and low-nitrogen material, and a high-purity material.

\section{REFERENCES}

1. Price, C., Lawrence Livermore National Laboratory, personal communication.

2. Savage, W. F., “1980 Houdremont Lecture: 'Solidification, Segregation, and Weld Imperfections,' "Welding in the World, Vol. 1, No. 5/6, 1980, pp. 2-17.

3. Hansen, M., Constitution of Binary Alloys, McGraw-Hill Incorporated, 1958.

4. Shunk, F. A., Constitution of Binary Alloys, Second Supplement, McGraw-Hill Incorporated, 1969.

5. Keith, G. H., and H. G. Iverson, Some StrainAging Effects in Electrorefined Vanadium, Bureau of Mines Report of Inv. 7222, (1969).

6. Matthews, D. R., G. H. Keith, and E. A. Loria, Effects of Interstitial Impurities on the Mechanical Properties of Electrorefined Vanadium at Low Temperatures. Bureau of Mines Report of Inv. 6637, (1965). 


\section{L L U S T R A T I O N S}

(Figures 1 Through 19)

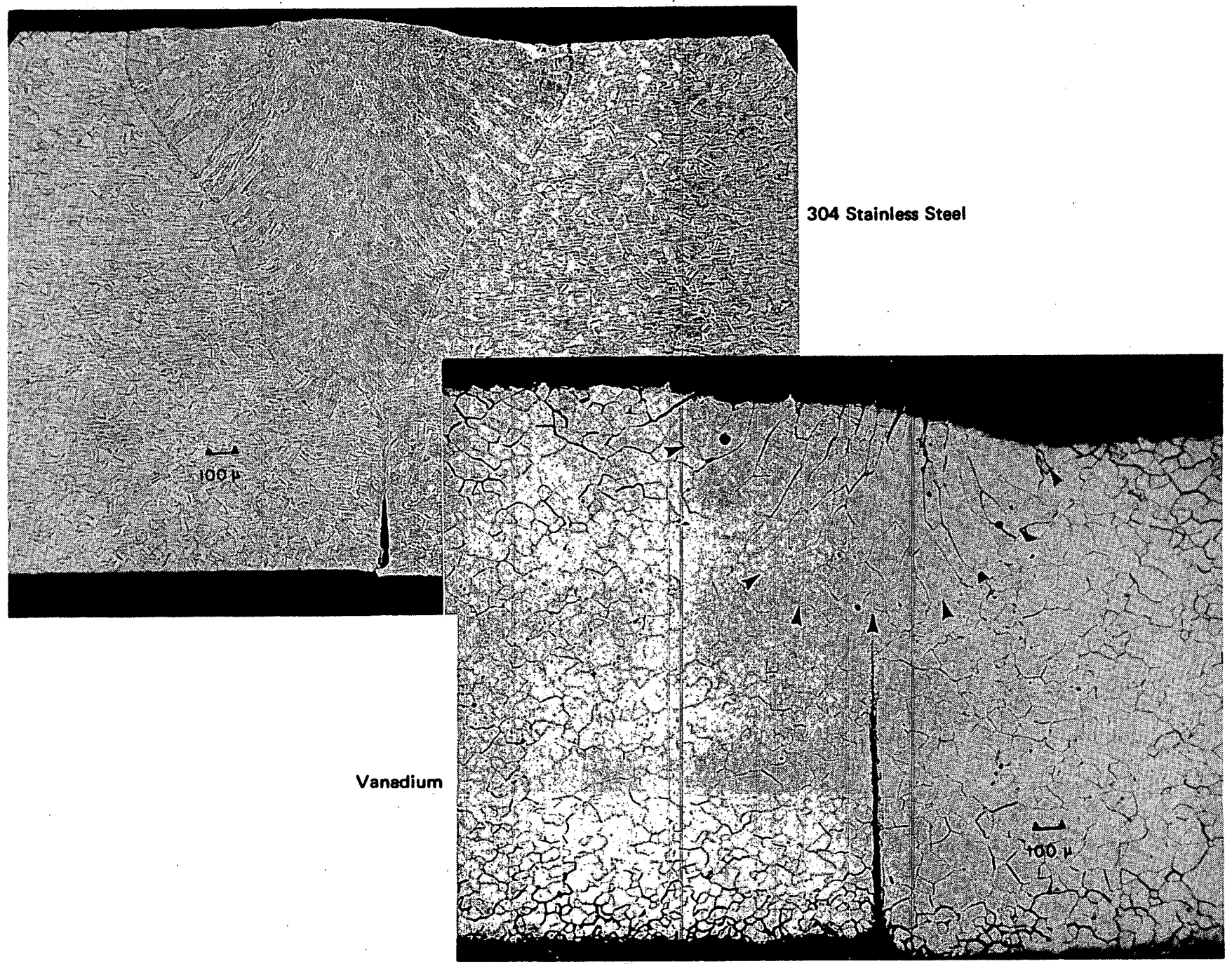

FIGURE 1. Vanadium and 304 Stainless Steel Electron Beam Welds Made With Identical Parameters. Arrows on the vanadium weld delineate the weld fusion zone. 37X 
RFP-3217

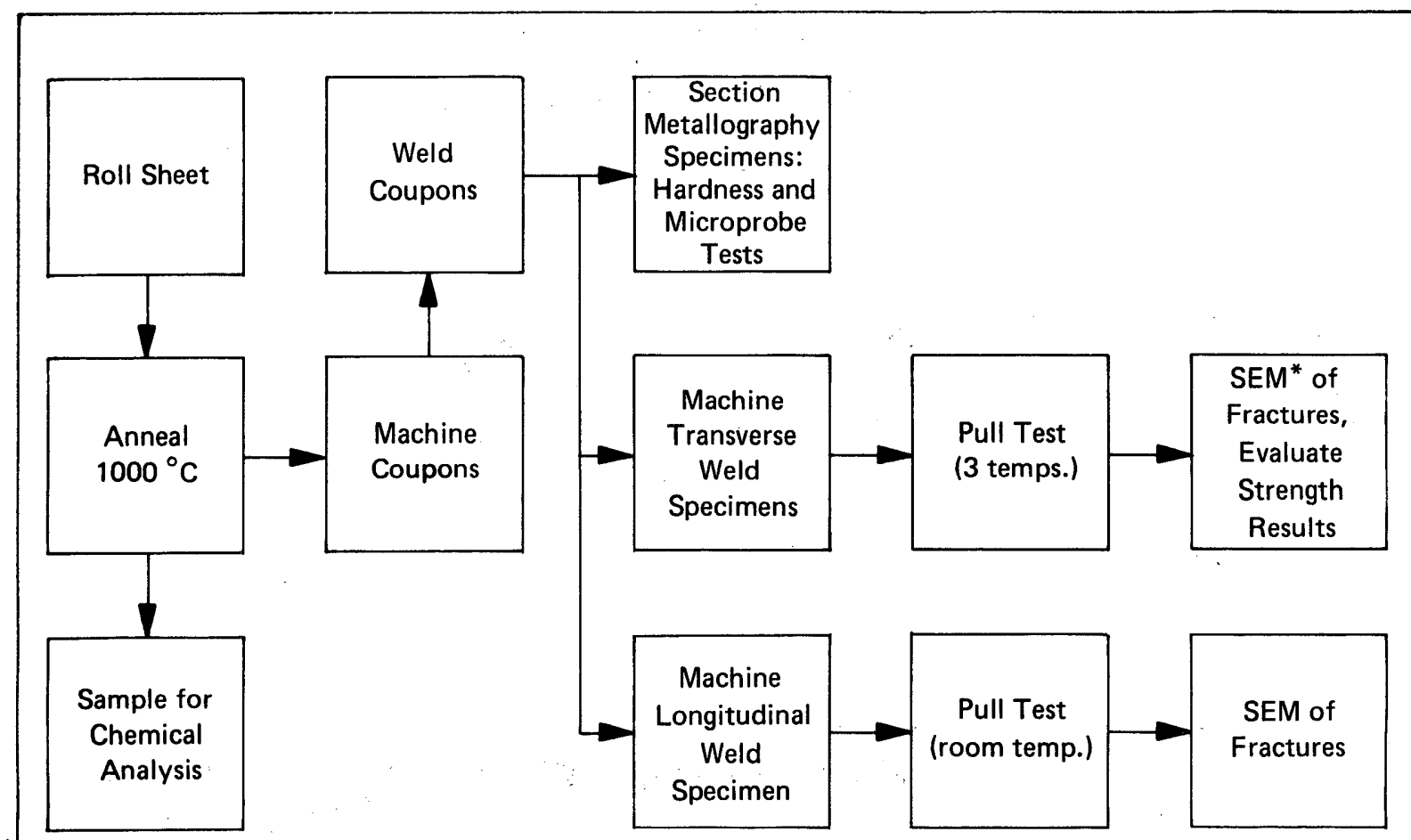

Note: SEM - Scanning Electron Microscopy

FIGURE 2. Flow Diagram of the Experimental Procedure

FIGURE 3. Design of the Transverse Weld Specimens

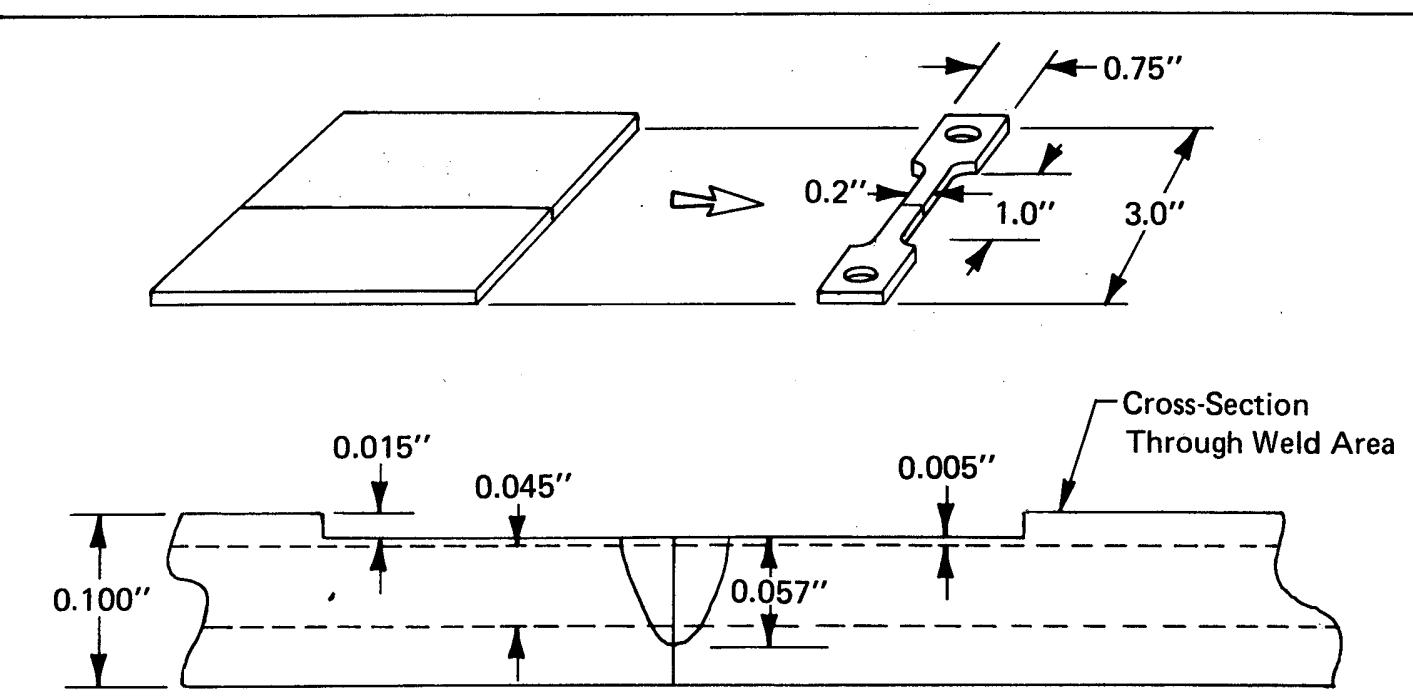


RFP-3217

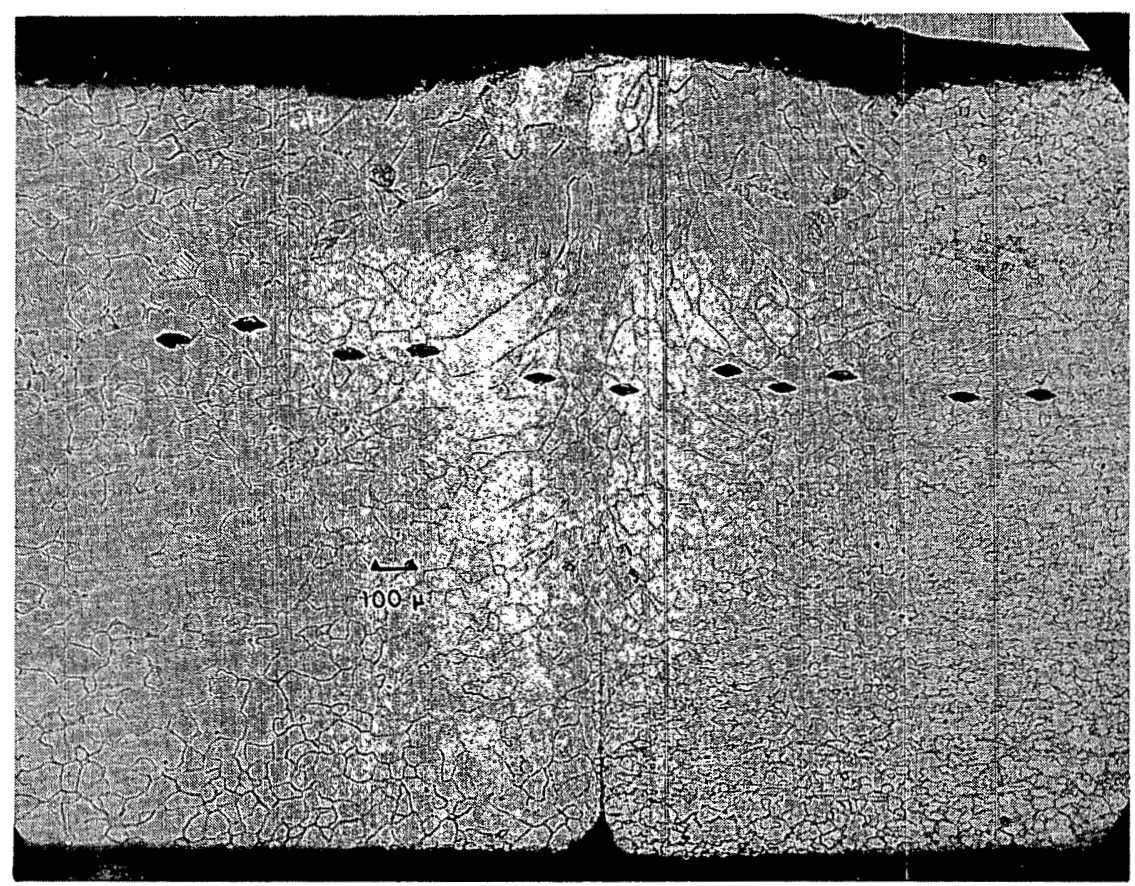

FIGURE 4. Cross-Section of the Weld in the UM Material Perpendicular to the Weld Axis. The grains on the right are smaller because of the smaller-grained parent material. The depressions are Knoop hardness idents. 35X

FIGURE 5. Cross-Section of the Same Sample as Figure 4, but Oriented $30^{\circ}$ From That of the First Section. This crosssection shows significant elongation of the grains. $25 \mathrm{X}$

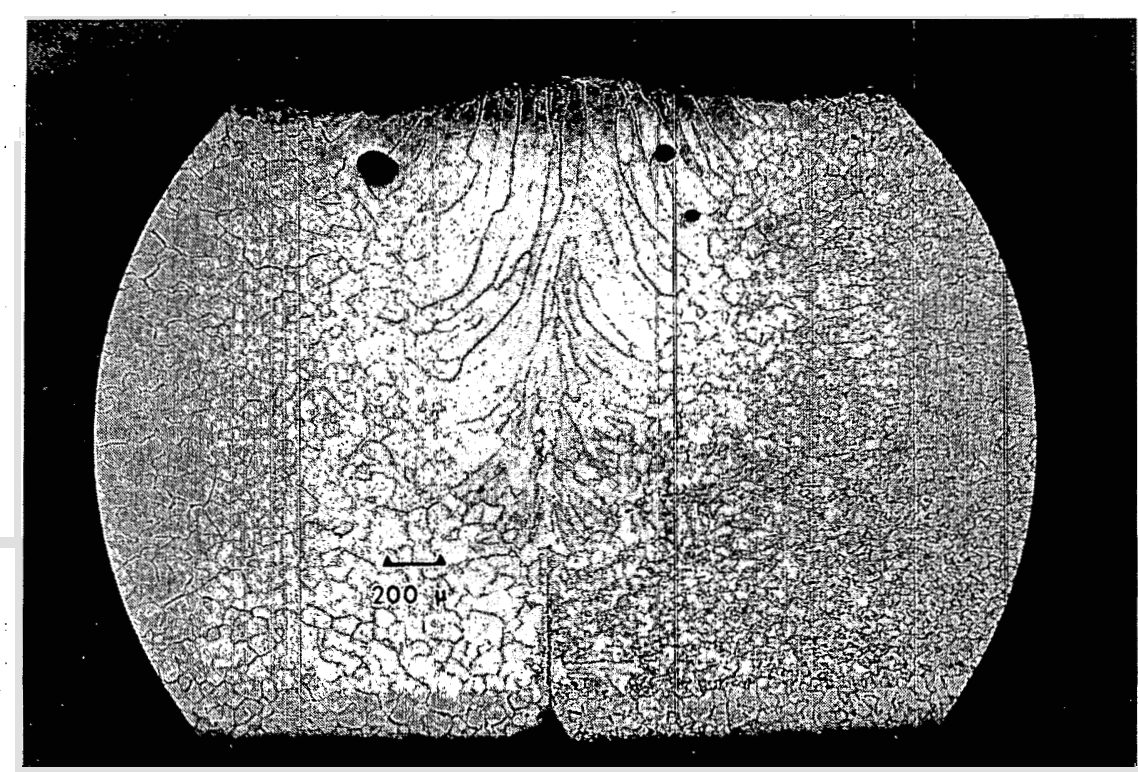


RFP-3217

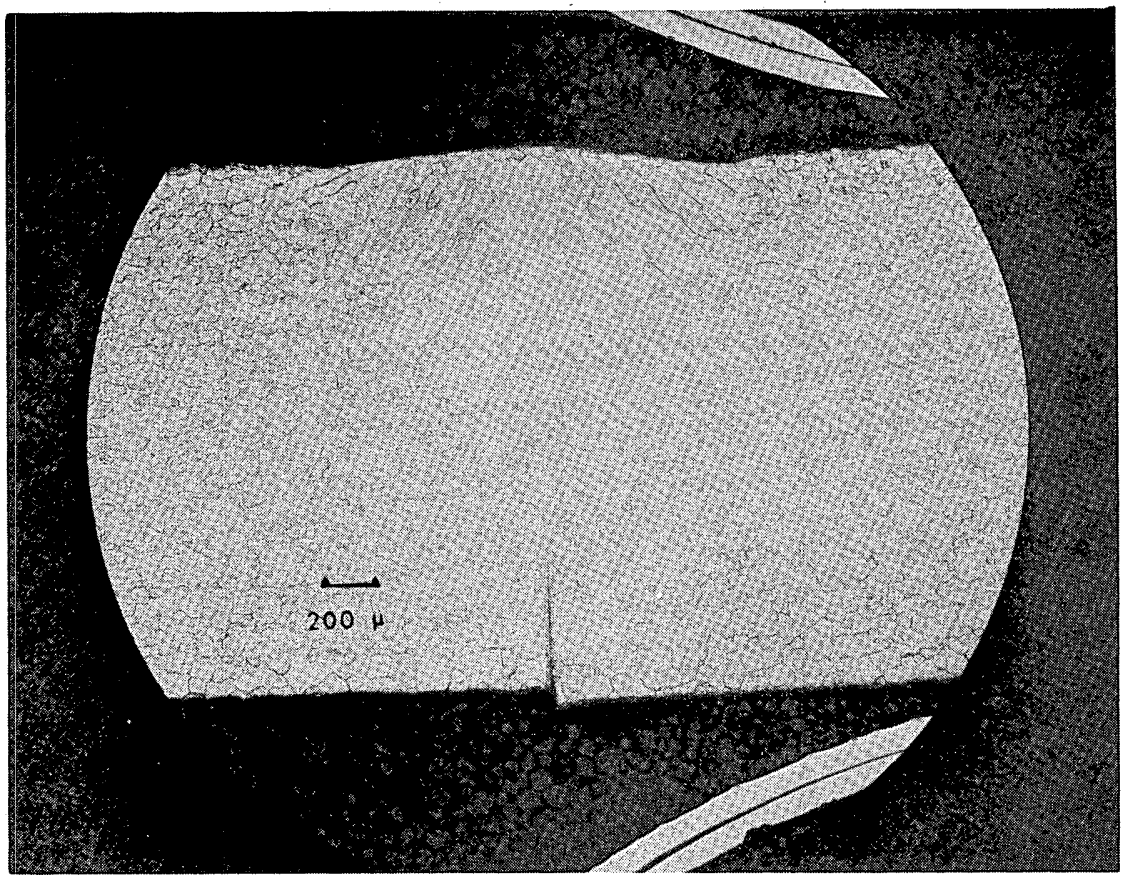

FIGURE 6. Cross-Section of the Weld in the $\mathrm{UM}+\mathrm{Si}$ Material. At low magnification, this weld is similar to that of the UM material. $25 \mathrm{X}$

FIGURE 7. Higher Magnification of Cross-Section of the Weld in the UM + Si Material Showing a Cellular Structure (differential interference contrast) $400 \mathrm{X}$

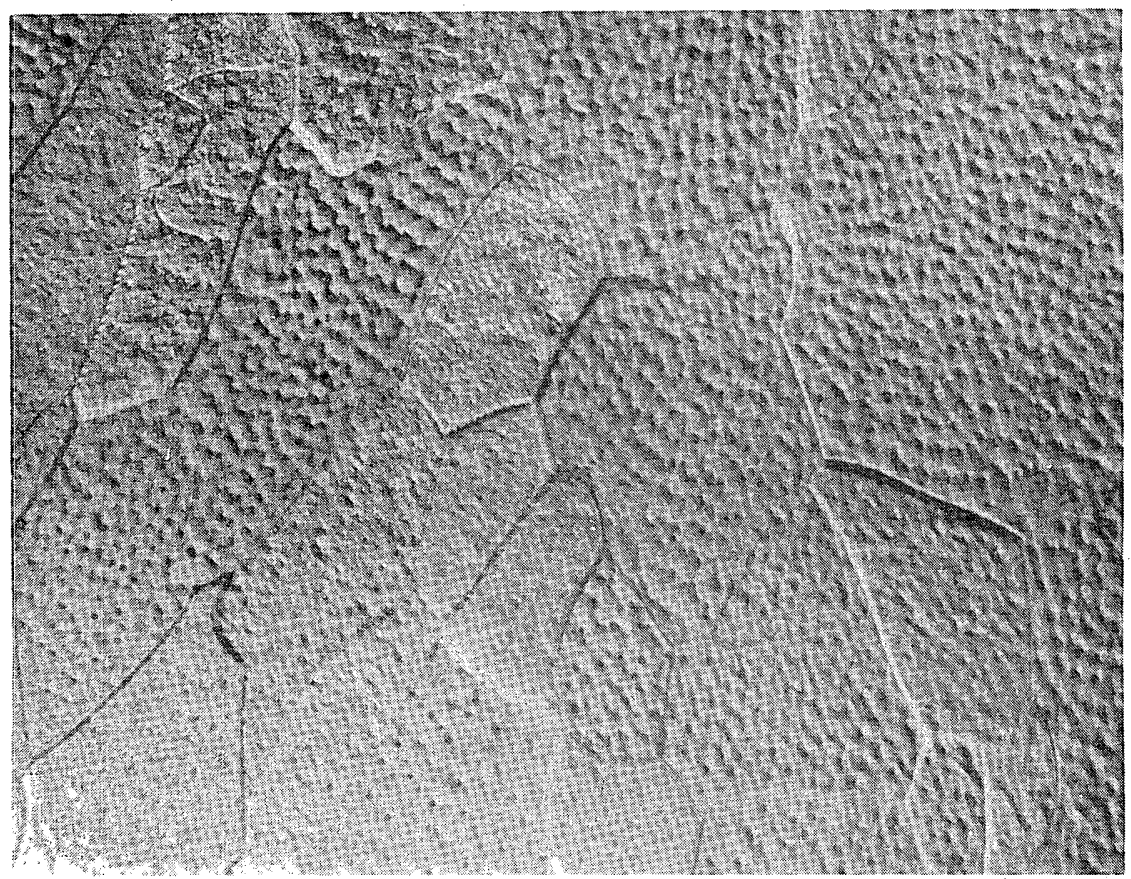




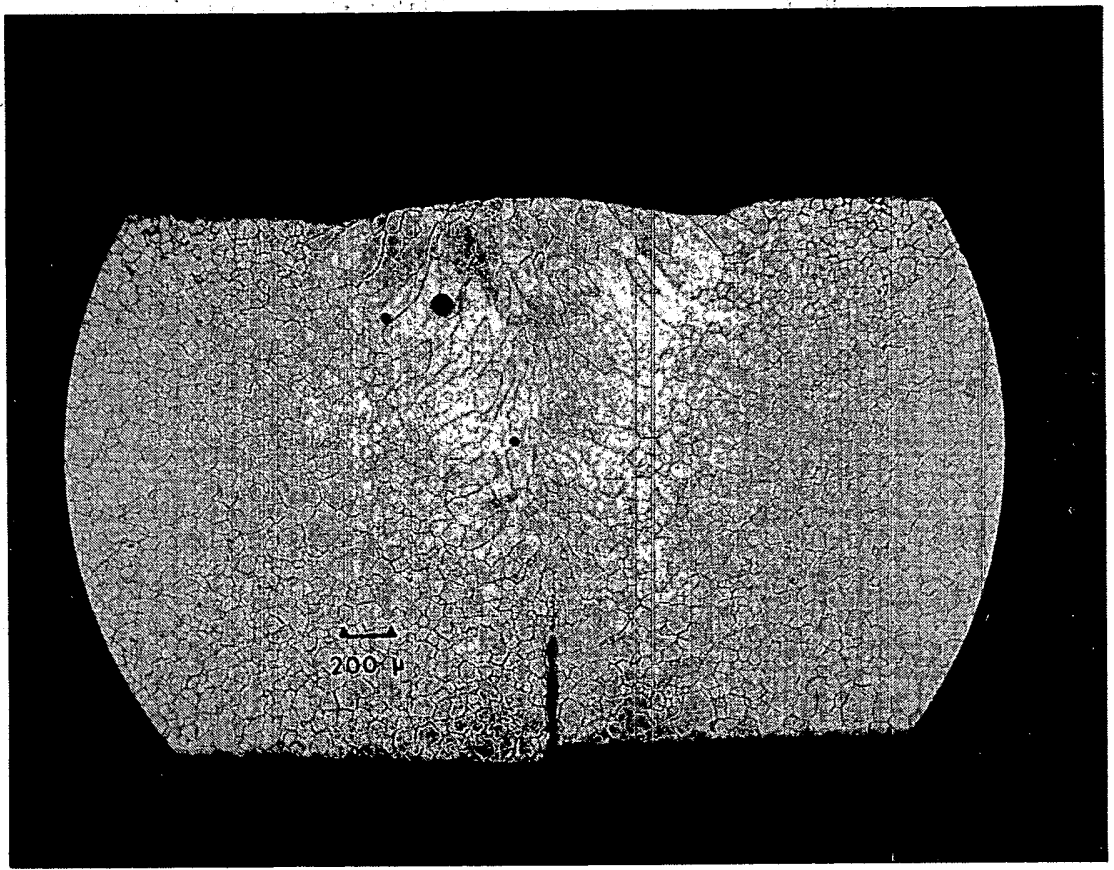

FIGURE 8. Cross-Section of the Weld in the A5-1 Material. Although this material exhibited much different mechanical properties than the $\mathrm{UM}+\mathrm{Si}$ materials, the weld structure is similar. $25 \mathrm{X}$

FIGURE 9. Hardness Profiles of the $\mathrm{UM}+\mathrm{Si}$, UM, and A5-1 Welds. The high interstitial materials showed an increased hardness in the weld area.

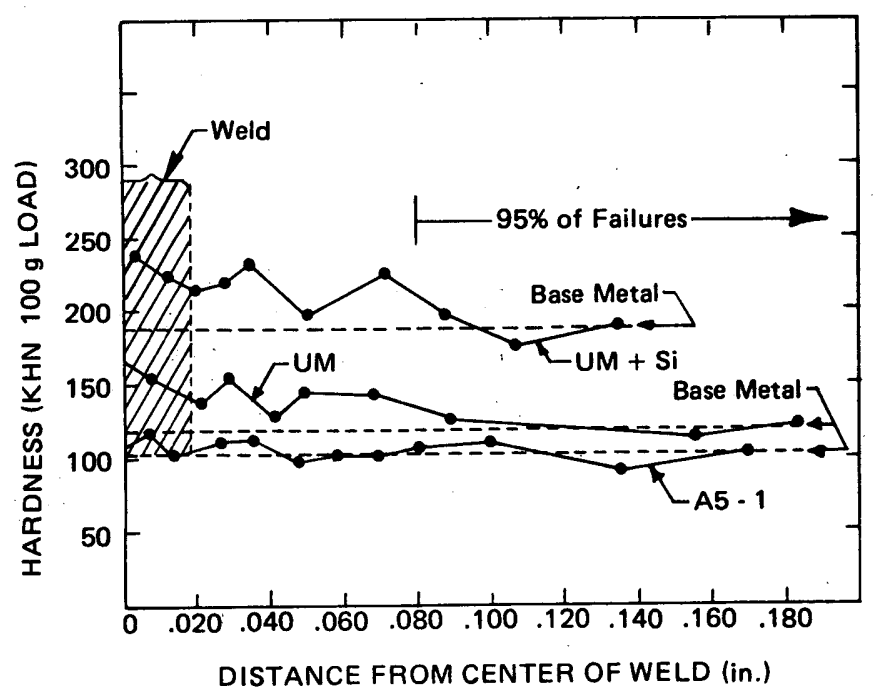

FIGURE 10. Hardness Profiles of the A6-1 and B6-1 Welds. No significant differences in hardness were found between the weld area and base material.

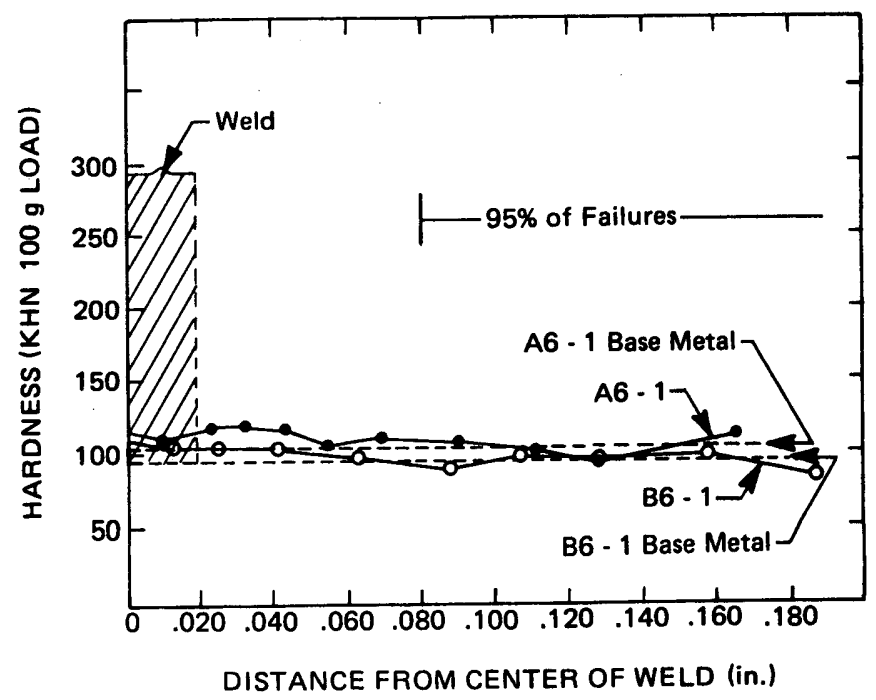


RFP-3217

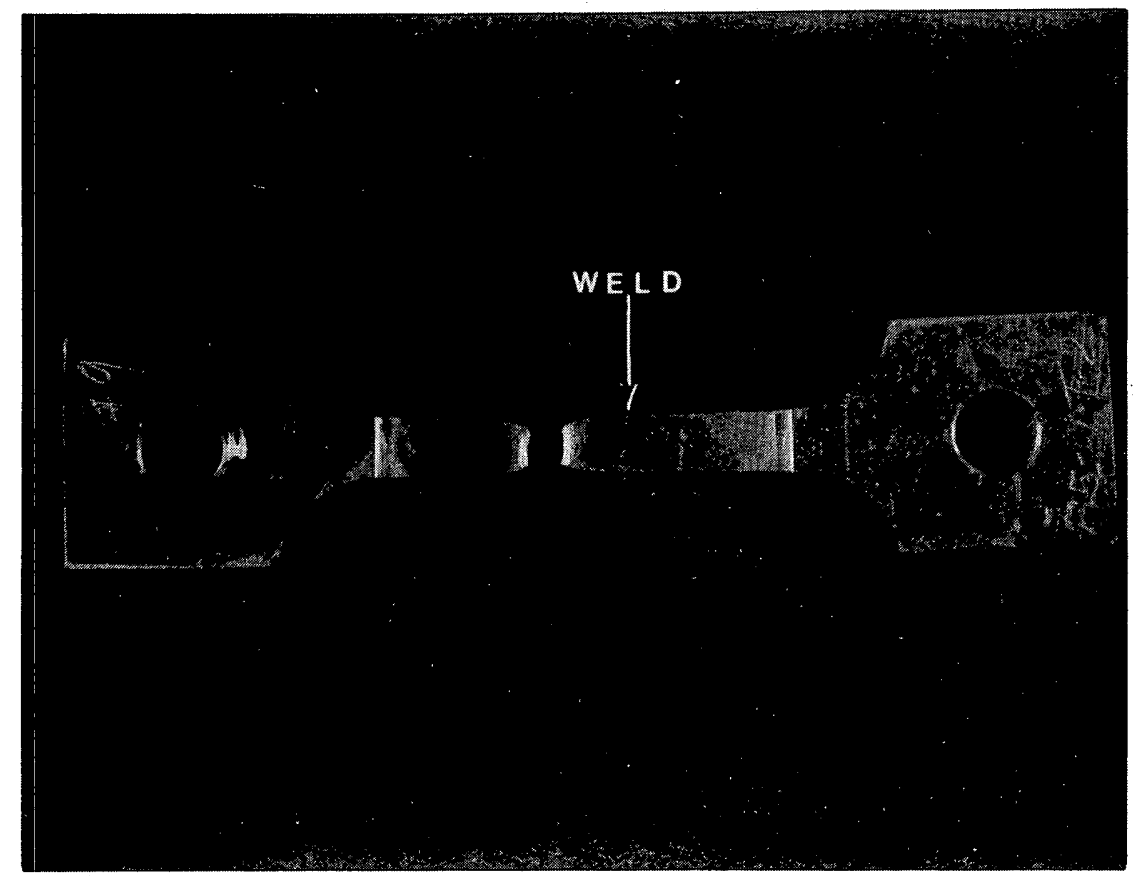

FIGURE 11. A Typical Pull-Tested Transverse Weld

Coupon Showing the Ductile Nature of the Failure 


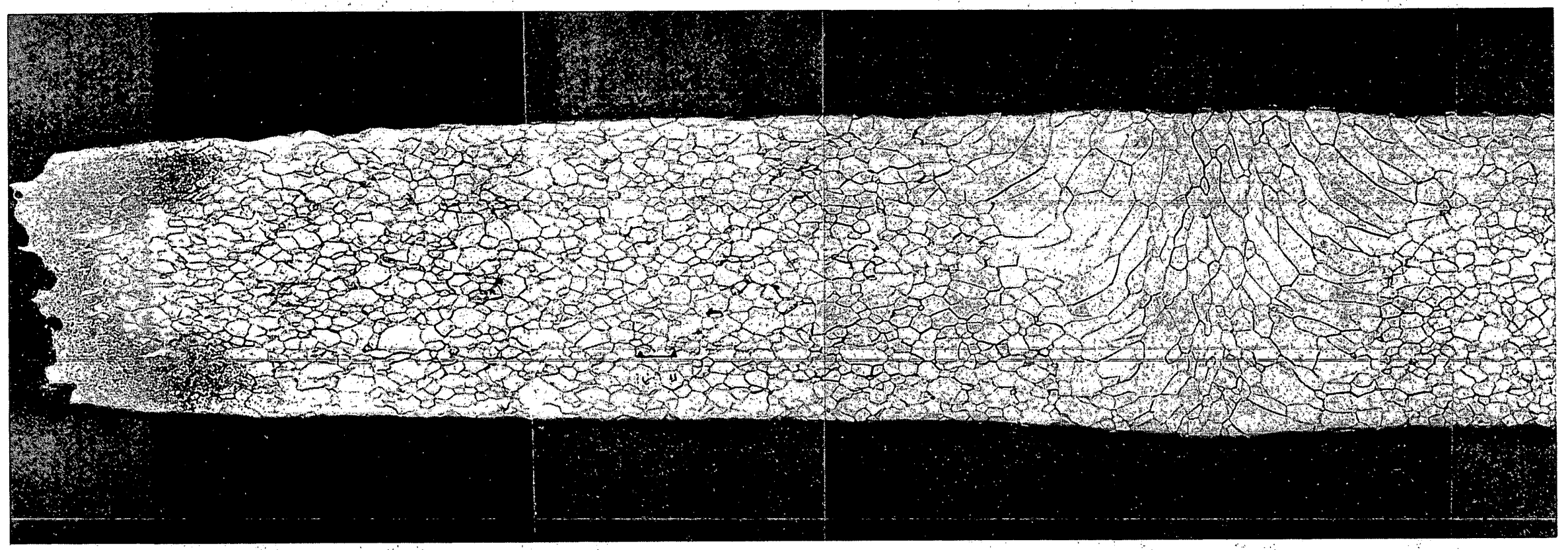

FIGURE 12. Cross-Section of a Tensile-Tested Transverse Weld Coupon of the A5-1 Material. This failure, typical of the materials tested, was a significant distance from the weld. 50X 


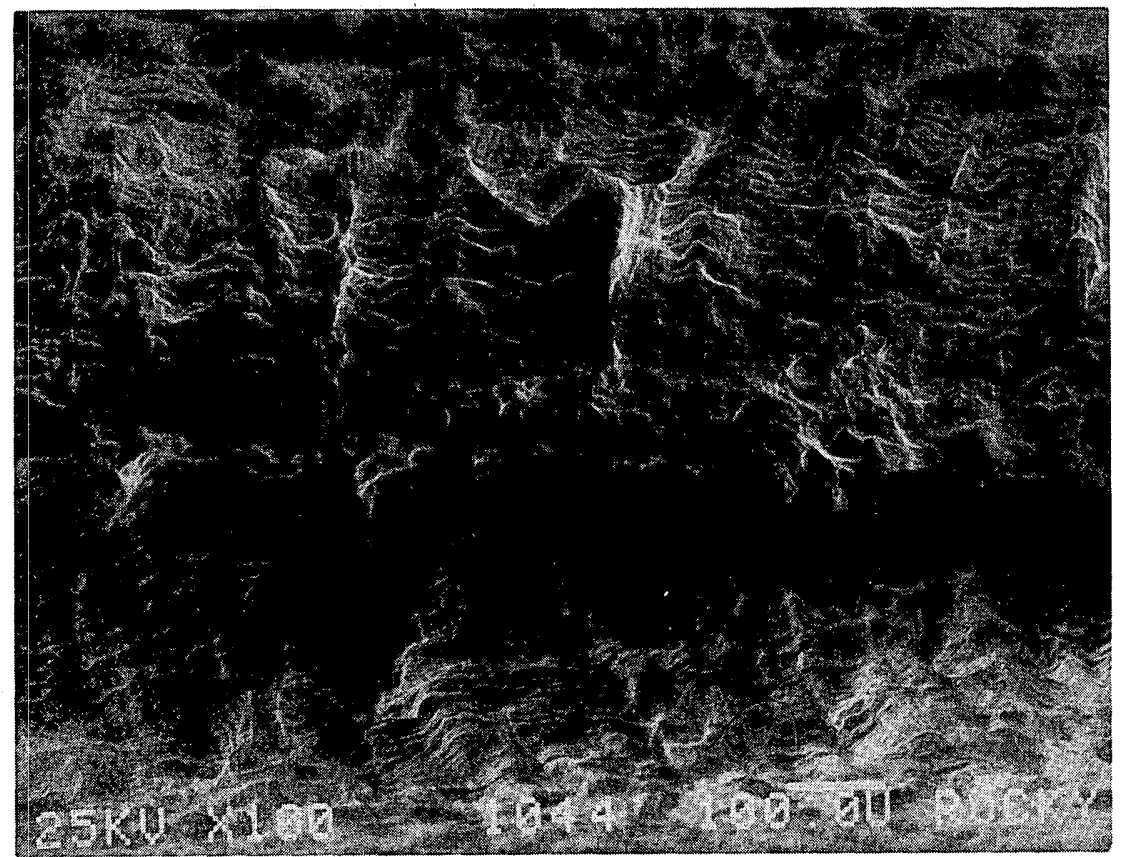

FIGURE 13. SEM Photograph of the Base Metal Fracture of the A5-1 Material. The smooth central band is the area of final fracture; the slip lines of necking are evident above and below this area. 100X

FIGURE 14. SEM Photograph of the Edge of the Final Fracture Area of the A5-1 Material. Some ductile-dimple failure mode is evident. 1000X

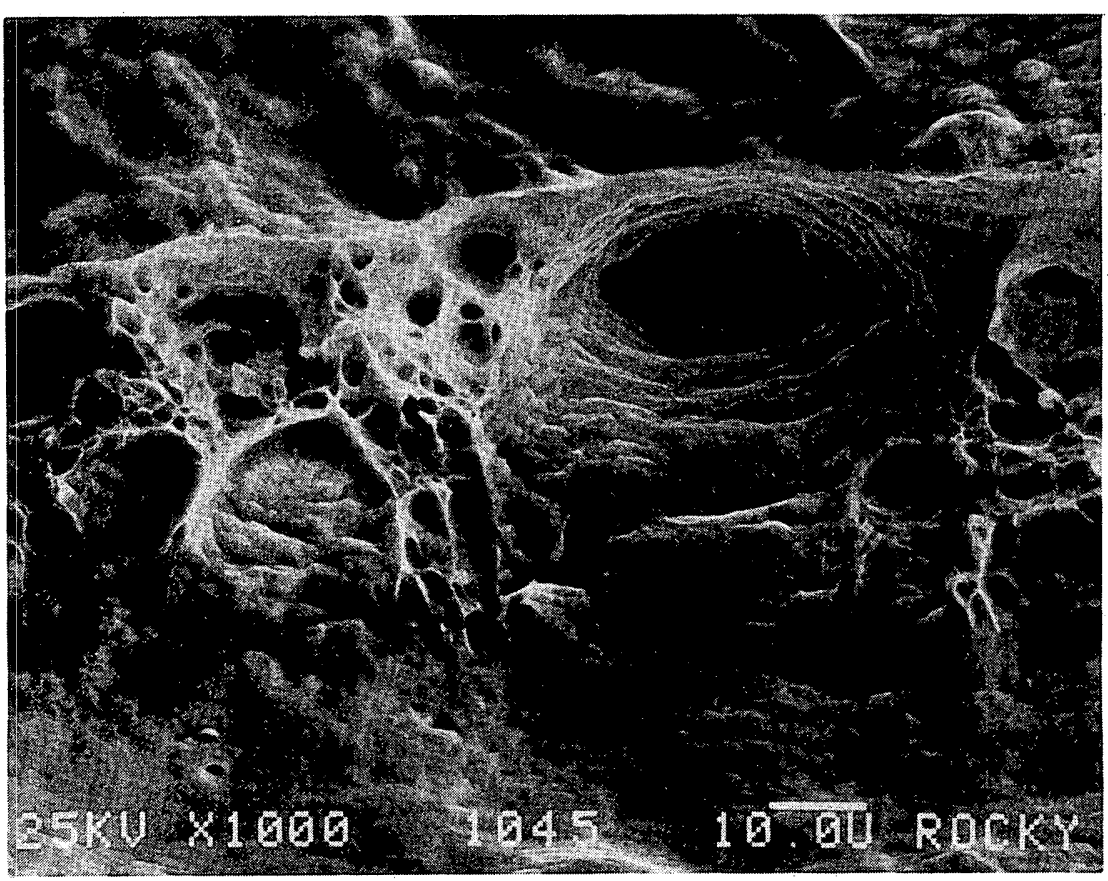




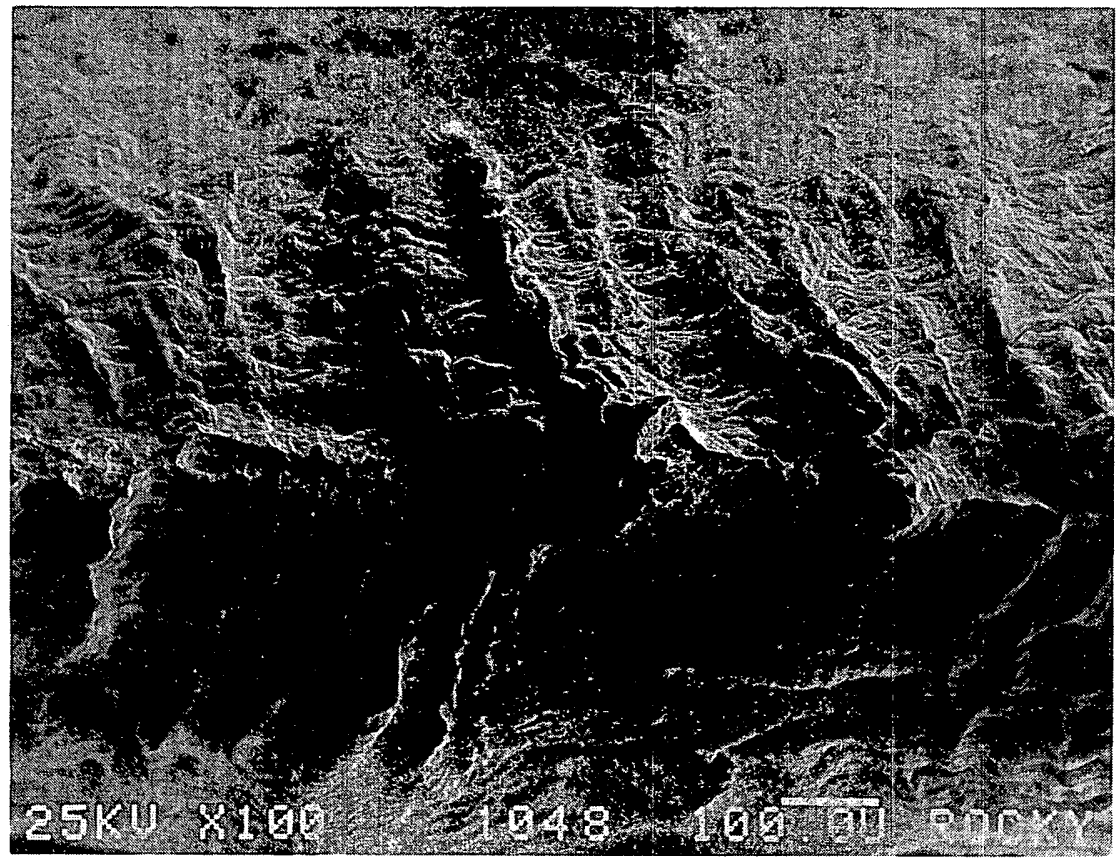

FIGURE 15. SEM Photograph of the Fracture in the Longitudinal Weld Specimen of the A5-1 Material. The center part of the final fracture is through the weld. $100 \mathrm{X}$

FIGURE 16. SEM Photograph of the Final Fracture Area Through the Weld of the Longitudinal Weld Specimen of the A5-1 Material. The failure mode is ductile-dimple. 1000X

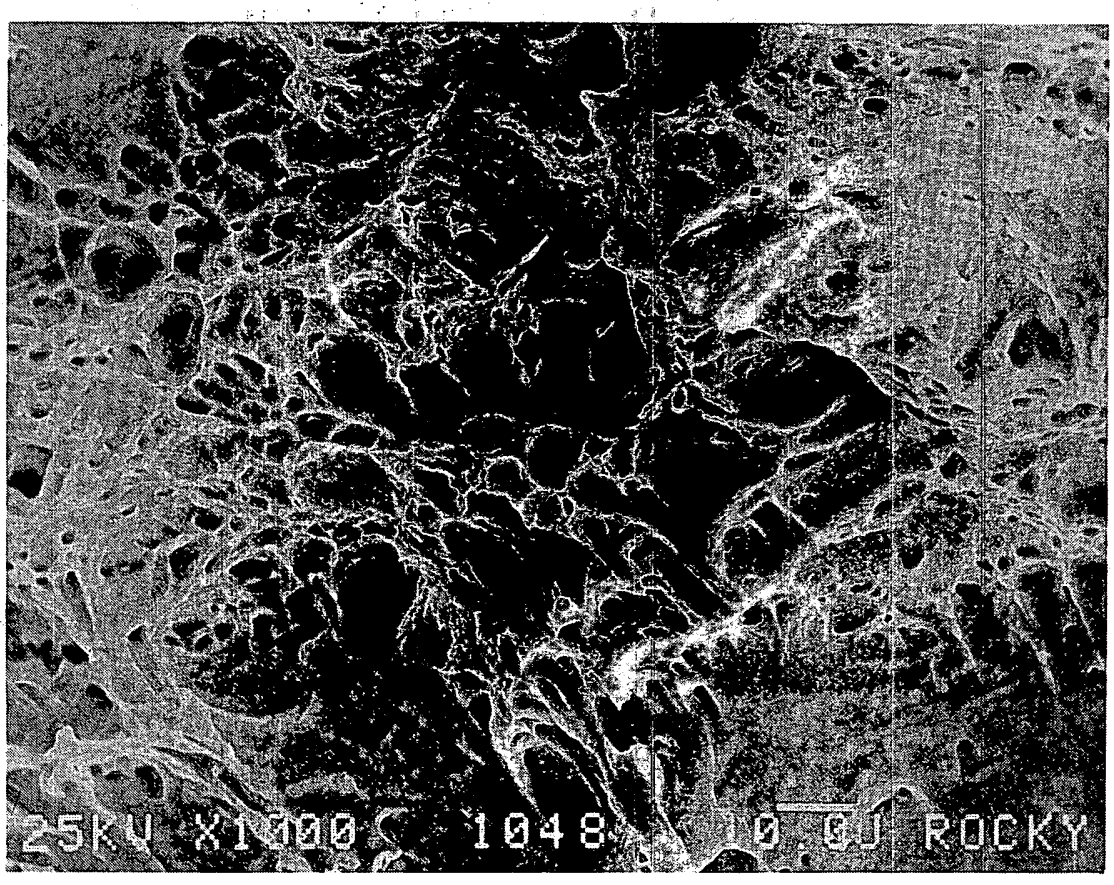




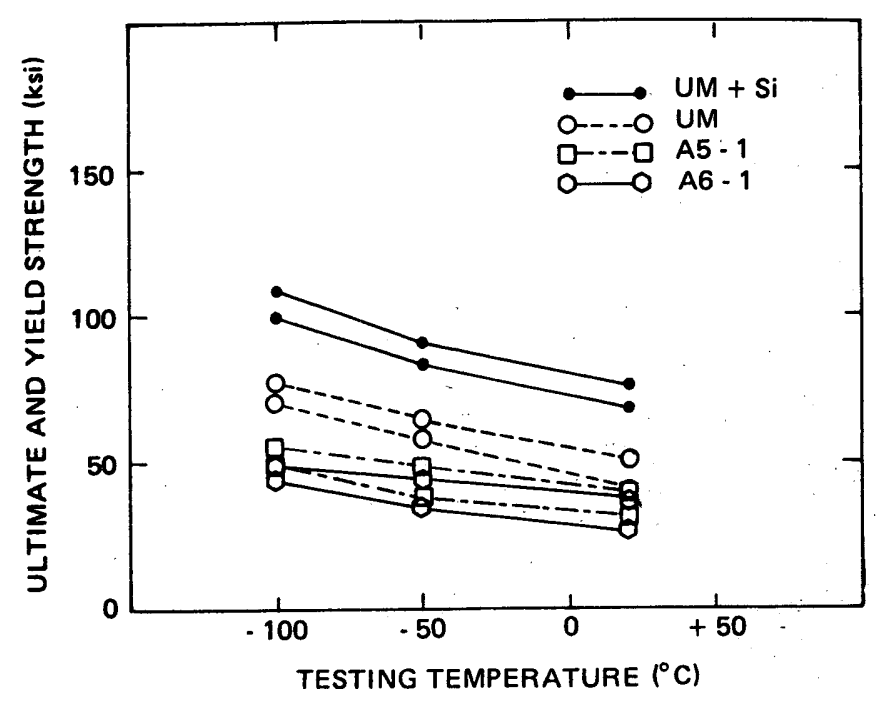

FIGURE 17. Effect of Testing Temperature on the Strength of Vanadium (Transverse Weld Specimens)

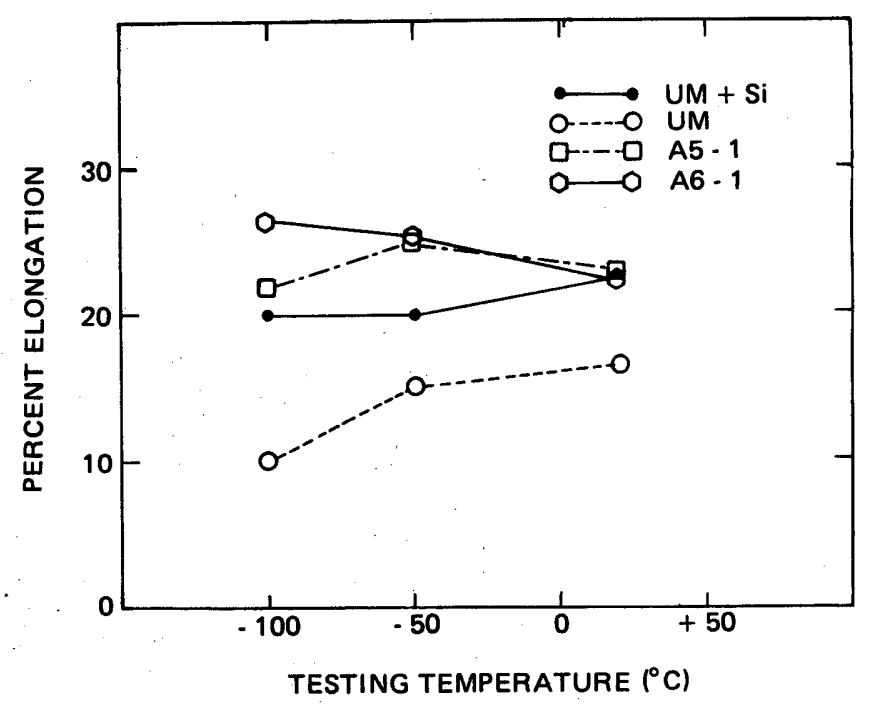

FIGURE 18. Effect of Testing Temperature on the Ductility of Vanadium (Transverse Weld Specimens)

FIGURE 19. Correlation Between Hardness and Strength, and Between Grain Size and Strength of the Vanadium Tested

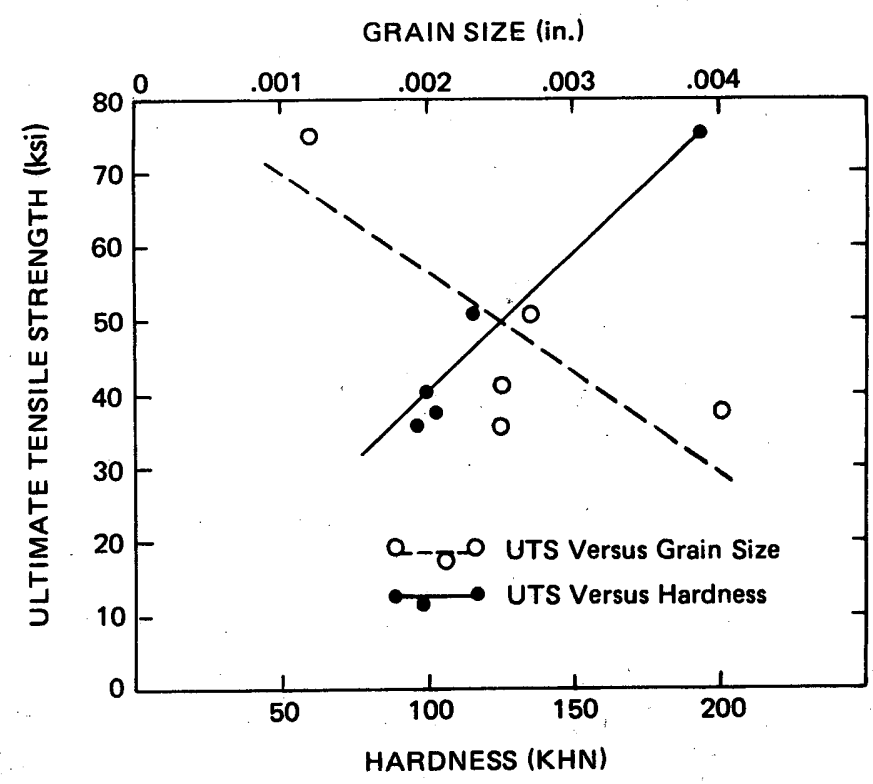

